\title{
Pusan 1997
}

\author{
By Toh, Hai Leong \\ Spring 1998 Issue of KINEMA
}

\section{SOME OBSERVATIONS OF ASIAN FILMS IN THE 2nd PUSAN INTERNATIONAL FILM FESTIVAL}

The 1997 Pusan International Film Festival (PIFF) witnessed a deluge of films -- new and old Korean films, Asian and international films, independent films, documentaries, and animations. Equally impressive was the response from the home crowd which appeared to have an insatiable appetite for internationally acclaimed films and young, famous Korean directors. (According to official records, the first PIFF attracted 200,000 people, this year, it seemed to be even more.) The 1997 festival opened with Wayne Wang's Chinese Box and closed with Ann Hui's Eighteen Springs at the 4,200-seats Pusan Yachting Centre Outdoor Theatre which also happens to be Asia's largest outdoor screen equipped with a digital sound system. Situated in Haeundae, Pusan's well-known beach resort, it was also where popular Hollywood fare such as G.l. Jane, One Night Stand, Bean, and crowd-pleasing Asian films like Opium War, Shall We Dance?, and the incisive Korean political satire 3 pm Paradise were shown.

To facilitate easy access and avoid having viewers run from one place to another, the main festival venues were all within two blocks of each other -- Busan (1,2,3), Jeil, Kukdo, Academy, Puyong. The streets outside were filled with attractive tents devoted to selling all manner of festival paraphernalia.

Adulation of Korean stars became a new festival phenomenon this year as wide-eyed Korean teenagers went wild over Jun Do-yun, the pretty lead actress of Jang Yoonhyun's The Contact (1997) -- not to be confused with Robert Zemeckis' Contact (1997) starring Jodie Foster. Jang's film is a highly celebrated version of the Japanese teen cult movie Love Letter by Shunji Iwai, a fantasy about love-via-e-mail championing emotional and spiritual love over simple physical contact. Such was the enthusiasm for Ms. Jun that the entire audience stayed after the screening of the film to hear what she and the director had to say. On her way out, the actress was mobbed by the screaming crowd so that the security police had to form a cocoon around her. Since this sort of adulation is usually reserved for glamorous Hollywood and Hong Kong movie stars, Ms. Jun's popularity in her home country is quite an achievement.

A few days earlier, Hong Kong superstar Tony Leung Chiu-wai (Cyclo, Happy Together) had been duly swarmed by his fans and female admirers when he appeared for the screening of Wong Kar-wai's Happy Together in which he plays one of the male leads. This "gay" film was shown to a limited audience including press and festival guests since it had been banned from distribution by the state-run Korea Public Performance Ethics Committee.

A cooler reception awaited talented young director Kim Ki-duk at the Puyong Theatre. A painter by training, Kim arrived without his cast, accompanied only by the PIFF interpreter. The thinner crowd meant a better deal for the foreign press and festival programmers as there was more time for discussion with the director. We all had a better understanding of the kitsch film, Crocodile (1996), a tale of a "dirty young man" who preys on suicide victims by hiding their corpses and extorting ransom money from their relatives.

All in all, the PIFF presented more than 240 films (including shorts) from 33 countries in several program sections, including: New Currents (11 films in competition for the New Currents Jury Award and the FIPRESCI Award ), A Window On Asian Cinema (17 films from East Asia and Pacific Rim ), Korean Panorama (10 films competing for the Korean Cinema Recognition Awards and the NETPAC Award), World Cinema (21 films), Wide Angle (53 films vying for the Woonpa Award given to Best Korean Independent Film and the Sonje Award for the Best Foreign Independent Film), Asian Documentaries (17 films), Documentaries of the Masters (4 films), Animation Works (8 films), Open Cinema (9 films) at the Yachting Center Outdoor Theatre and the Retrospectives (adding up to 44 films including a section on Hong Kong Cinema: A Special Retrospective comprising Images of Hongkong popular with Korean viewers and New Discoveries which scrutinises Asia's cities and Early Asian Cinema: Close Encounters with Asia's Past). 
The PIFF also organised the Pusan Promotion Plan '97, "a co-financing and co-production market bringing together indie Asian film projects with international funding sources", according to its promoters. This year, seminars and discussion panels were organised for the first three days of the festival at Pusan Hotel with directors, film archivists, scholars, critics and writers in attendance to discuss various aspects of the complex film trade. Next year, the PPP ' 98 will invite Asian producers and directors to meet with financiers, distributors, sales agents and other funding sources.

Like its more mature and established cousin, the Hongkong International Film Festival (HKIFF), the PIFF is distinguished for its fine exhibition of its national filmmakers' works for overseas distribution and also for highlighting the best Asian films for distribution in Korea. It is different from the non-competitive HKIFF only by its committed endorsement in awarding cash-rich prizes to deserving filmmakers from abroad and especially at home. Sad to say, although Korean directors like Park Kwang-su (Chilsu and Mansu, Berlin Report), Jang Sun-woo, Park Chul-soo (Farewell, my Darling), and Im Kwon-taek have attained national and international recognition for their cinematic achievements, they have yet to find a firm foothold in Asia where Hollywood cinema is now embedded in the popular consciousness and culture.

While the Wayne Wang film, Chinese Box was not a disagreeable choice as the prestigious opening film of the festival, some found it disappointing for failing to involve the audience with its implausible ménage $\grave{a}$ trois. Set in the days just before the historic handover of Hong Kong to China, Jeremy Irons plays a dying British journalist in the colony in love with a bar owner, Vivian (Gong Li) who in turn loves an emotionally constipated and status-conscious businessman Chang (Michael Hui). Intertwined in all this is the journalist's unsuccessful attempt to help a streetwise girl Jean (Maggie Cheung).

The eternal triangle also surfaced in Kwak Ji-kyun's film, Deep Blue starring the lovely Kang Soo-yeon as Eunsuh, a violinist torn between the love of two childhood friends. The long-suffering Hyunseh gets Eunsuh, then abuses her out of jealousy as she loses her heart to Whan. Later, Whan becomes a gangster and toy boy of a powerful triad boss' daughter. Needless to say, we all know the consequences of such trysts.

The comic and serious incidents in an Obstetrics and Gynecology hospital in Park Chul-soo's Push! Push! are depicted in his incisive collage style perfected in his previous film Farewell, My Darling. In his latest film, Park questions and explore the fundamental issues of single motherhood, sexuality, abortion, test-tube babies, male heir preference and reconstructive vaginal surgery, the two latter age-old "rights" of obsessive Korean patriarchy, and ultimately the eternal clash of tradition and modernism. By any standards, it is a major work which will stand the test of time to become a classic.

Controversial rebel Jang Sun-woo ( A Petal, From Me to You) has come up with a movie this year irreverently titled Timeless, Bottomless, Bad Movie, a middle-class-offending and angry film about Korea's deviant youths, slackers, homeless, beggars and the dregs of Korean bourgeois society in the tradition of Frederic Wiseman. The stories are scripted by the film's "bad" boys and girls based on their experiences and as painfully cruel as only real life can be. These include the portrayal of corporal punishments meted out by adults to defenceless but defiant students and the outrage of modesty suffered by a young hostess. The film carries the warning "strongly recommended for people with conscience!" but the State's moral guardians apparently disagree since they have subjected the film to censorship and violent objections. Nevertheless, Timeless, Bottomless, Bad Movie won the top prize at this year's Tokyo International Film Festival.

The recurring subject of this year's Asian films is about gangsters in modern Korea, Thailand, Hongkong and Japan. The loudest and arguably, the most poetic and violent, is Takeshi Kitano's back-to-form yakusa-cop film, Hana-Bi (1997), literally meaning "fireworks." A recipient of the 1997 Venice Film Festival Golden Lion for Best Film, Hana-Bi is an excellent study of the life of Nishi (Kitano), an out-of-work detective spending time with his dying wife, trying to elude loan sharks, the police and a traumatic shooting incident which left his best friend Horibe crippled. This time, Kitano mixes his characteristic brutal violence with a romantic elegy never before seen in his earlier films like Violent Cop, Boiling Point and Sonatine.

Usually obscure and inscrutable, Thailand was brilliantly represented by two gangster films. Nonzee Nimibutr's Dong Bireley and Young Gangsters set in the 1950s is a fact-based story of a prostitute's son who turns to organised crime while Pen-ek Ratanaruang's Fun Bar Karaoke tells the tale of $\mathrm{Pu}$ and her father whose dalliance with a gangster's moll nearly kills him. 
Hong Kong's most artistically accomplished film this year was unmistakably Fruit Chan's independentlyfunded film, Made In Hong Kong, a non-glamorous depiction of triad punks about a small-time gangster who befriends a mentally handicapped man and who falls for a girl with an incurable heart disease.

Arguably the best Korean triad film this year is scriptwriter-turned-director Lee Chang-dong's Green Fish, an allegorical tale about a naive young man, Makdong (Han Suk-kyu of Contact and Gingko Bed fame), who is inducted by the scheming Big Brother (Moon Sung-keun) to do all his dirty work including murdering his ex-boss, Shark. As an incentive, Big Brother uses Makdong's fascination with his sensual singer-moll to achieve his objective.

Homosexuality as a fashionable subject reared its disturbing head again in three major films. Two were from Hong Kong: Happy Together by maverick director Wong Kar-wai which was shown to a limited audience and Shu Kei's A Queer Story. The third was The River by Taiwan-based director Tsai Ming-liang.

Shu Kei's film is a "coming out" story which focuses on the dilemmas that open gays (Jordan Chan), middleaged gays (Law Kar-inl and especially closet gays (George Lam) encounter in life and in heterosexual society. Wong Kar-wai's celebrated (un)Happy Together could have been any love story between a man and a woman. This overrated film is an intense study of a male couple (Tony Leung Chiu-wai and Leslie Cheung) in lust with each other and hurting each other nastily (Wong's signature theme of the strong dominating the weak). The one betrayed (Cheung) finds solace in the arms of a young Taiwanese (Chang Chen) and they leave together for Taiwan. There is, however, a pirated video compact disc copy of the film circulating around which ends with Tony Leung at his dream destination, Niagara Falls, wishing for the return of Leslie Cheung. Happy Together is banned from distribution in Korea.

Wong, like many great film auteurs such as Robert Bresson, Michelangelo Antonioni, Jean Luc Godard, Federico Fellini, and Rainer Werner Fassbinder, seems to be making that first film over and over. His previous films including As Tears Go By, Days of Being Wild, Ashes of Time, Chungking Express and Fallen Angel all deal with the sober consequences of domineering love.

Tsai Ming-liang's The River is a bit more complex as it deals not only with male homosexuality per se but also a dysfunctional family in Taipei. The protagonist's retired father goes to saunas for furtive reasons while his mother has an affair with an apathetic pornography tape pusher. His own one-night affair with a former classmate is never followed up. The characters are all inarticulate, reflecting their inability to communicate. The film also has its moments of hilarity. Celebrated Hong Kong filmmaker Ann Hui plays herself as a director who persuades Lee Kang-sheng into doubling for her as a corpse floating in a polluted river (metaphor for Taiwan). The fake corpse is so unconvincing that it fails the test even on a small TV screen.

The only tribute to human endurance and courage are to be found in two great veteran filmmakers' works. The first is by acclaimed Fifth Generation Chinese filmmaker Huang Jianxin whose accomplished cop film Surveillance is a psychologically complex study of a dedicated security guard. The other film is by Kei Kumai, the maverick 67-year-old director who is still chipping away at the issues surrounding the ostracism of lepers in the early years of the draconian Leprosy Prevention Law. Kei Kumai's To Love is a story of young love between Tsutomu and Mitsu which is not thwarted by disapproving parents or society but by leprosy. When Mitsu finds she has been wrongly diagnosed, she decides to stay in the sanatorium to help the lepers, ultimately paying the price for her action.

The most stylish film is Park Ki-yong's Motel Cactus, shot by Chris Doyle, the cinematographer who has worked with virtually all of Asia's best directors including Stanley Kwan, Chen Kaige, Wong Kar-wai, and Stan Lai. The film deals with four different tales set in the same room of a "love motel" in Seoul. The characters in the four episodes are infused with a sense of angst and loneliness as they struggle with meaningless sex, the inability to cope with change, or simply living in the past.

There was some consternation among international film festival programmers that the latest film by the respected Korean director Im Kwon-taek, Chang, was not included in this year's screenings at Pusan. The reason given was that Im's producer was saving his latest masterwork for the Cannes competition in 1998. It seemed unfortunate that the film did not get shown at the festival since it is possible for a film which has 
been screened at its own country's film festival to compete. Nevertheless, the Korean public could still see the film at two cineplexes in Pusan at the time of the festival.

\section{Author Information}

TOH Hai Leong is a Singapore-based freelance film critic and filmmaker (Zombie Dogs, 2005) who writes for independent film publications such as Screen International and World Paper. He has covered the Hong Kong International Film Festival since 1985 and specializes in the cinemas of Hong Kong, Taiwan, China, Korea and Japan. 